\title{
Waste Management in Industrial Construction: Investigating Contributions from Industrial Ecology
}

\author{
Larissa A. R. U. Freitas ${ }^{1,2, *}$ and Alessandra Magrini ${ }^{1,2, *}$ \\ 1 Energy Planning Program, Alberto Luiz Coimbra Institute for Research and Post Graduate Studies of \\ Engineering, Federal University of Rio de Janeiro, PPE-COPPE-UFRJ, Rio de Janeiro 21941-972, Brazil \\ 2 Centro de Tecnologia, Bloco C, sala 211, Cidade Universitária, Ilha do Fundão, Caixa Postal 68.565, \\ Rio de Janeiro 21941-972, Brazil \\ * Correspondence: lariutiyama@yahoo.com.br (L.A.R.U.F.); ale@ppe.ufrj.br (A.M.); \\ Tel.: +55-13-98104-0047 (L.A.R.U.F.); +55-21-3938-8761 (A.M.)
}

Received: 28 May 2017; Accepted: 10 July 2017; Published: 18 July 2017

\begin{abstract}
The need for effective construction waste management is growing in importance, due to the increasing generation of construction waste and to its adverse impacts on the environment. However, despite the numerous studies on construction waste management, recovery of construction waste through Industrial Symbiosis and the adoption of other inter-firm practices, comprised within Industrial Ecology field of study, have not been fully explored. The present research aims to investigate Industrial Ecology contributions to waste management in industrial construction. The waste management strategies adopted in two industrial construction projects in Brazil are analyzed. The main waste streams generated are identified, recycling and landfilling diversion rates are presented and waste recovery through Industrial Symbiosis is discussed. A SWOT analysis was carried out. Results demonstrate that $9 \%$ of the waste produced in one of the projects was recovered through Industrial Symbiosis, while in the other project, waste recovery through Industrial Symbiosis achieved the rate of 30\%. These data reveal Industrial Symbiosis' potential to reduce landfilling of industrial construction wastes, contributing to waste recovery in construction. In addition, results show that industrial construction projects can benefit from the following synergies common in Industrial Ecology place-based approaches: centralized waste management service, shared waste management infrastructure and administrative simplification.
\end{abstract}

Keywords: construction waste management; industrial ecology; industrial symbiosis

\section{Introduction}

The construction industry permeates most of the economic sectors as it transforms various resources into the constructed infrastructure necessary for socio-economic development. However, despite its relevance for society, it is acknowledged that construction activities impact the natural environment [1]. Construction waste, for example, has become an important issue, due to its increasing generation and to its potential adverse effects on the environment [2]. Debris from construction and demolition projects constitutes $35 \%$ of solid waste in the world [3], corresponding to the largest waste stream generated in some countries [4]. In addition, although construction waste is mostly inert, lack of management practices focused on reuse, recycling and other recovery alternatives reduces landfill space and results in loss of natural resources [5].

Given the need to prevent and manage construction waste, several countries have developed and implemented a great number of environmental regulations, which specify limits for disposal in landfills, recycling goals, disposal fees and incentives to good waste management performance in construction projects $[3,6-8]$. Consequently, contractors must take active waste prevention, reduction, 
recycling and management actions within construction projects to deal with the various kinds of waste generated [2,9] and to assure legal compliance.

Researchers have pointed out that waste management in construction activities should start from the design and the procurement phases and, then, extend to onsite technologies and plans [10]. Project designers should spend some time on considering how to reduce waste generation through reasonable design schemes [11], use of secondary materials [12], as well as, standardization of construction materials, dimensional coordination and application of modern methods of construction [13].

In turn, regarding onsite management activities, adherence to design documents, reduction of the number and extent of design changes [13] and more accurate estimation of materials required in each construction stage [14] have been pointed as practices with great potential to reduce waste generation. Onsite management of construction waste is also considered determinant for its destination [15]. Waste segregation [16] and maximization of onsite materials reuse [17,18], for example, are practices that contribute for reducing waste landfilling and material intensiveness in construction. The importance of waste management plans to effective waste management in construction projects is also recognized [13], although its dissemination to all workers is one of the least widespread practices in construction [12]. The relevance of adequate supervision of waste management activities and collaboration between the actors involved are also highlighted in the literature [19].

Although much research has been done on construction waste management, contributions from Industrial Ecology (IE) field of study have not been deeply investigated. IE has emerged as a potential guide to restructure the industrial system [20] based on a set of principles, tools and perspectives derived from ecology [21]. In the last decades, IE principles and practices have widespread all over the world from the iconic example of self-organized symbiosis of Kalundbourg, through planned developments such as those driven by the Chinese National Policy for Eco-Industrial Parks (EIP) [22-25], up to initiatives that go beyond the industrial systems such as the Japanese Eco-town program [26]. Due to its potential contributions to material loop closing [27], IE principles and models got its importance renewed within the context of Circular Economy. Over the past years, Circular Economy has developed as a model that aims to increase the efficiency of resource use, through the adoption of material loop closing patterns in production systems [28]. Practices and tolls derived from several fields of knowledge are necessary to achieve Circular Economy's goals [29,30]. Within this context, IE plays a central role in the implementation of inter-firm approaches focused on the reintegration of waste and by-products on economy [31]. The experiences reported in the literature reveal IE potential to be applied in different social contexts and economic sectors.

The construction industry can be subdivided in two sectors: residential construction and industrial, commercial and institutional construction. Industrial construction encompasses the design, installation and maintenance of all structural and mechanical components in power plants, factories, refineries, mines, among others. It's a very specialized, niche form of construction. Typical industrial construction projects require substantial investment, involve many trades and disciplines (e.g., civil, steel structure, piping, electrical, mechanical) and have an extremely high level of engineering and construction activities, which are interwoven and tightly coupled with one another [32], enhancing its technical and managerial complexity.

In several industrial construction projects, contractors, subcontractors and other actors are co-located at the same project site, suggesting that IE place-based approaches could be adopted in order to reduce environmental burdens. Waste management synergies offered by geographical proximity are pointed out in IE literature as opportunities that, if well explored, can generate significant benefits [25,33-36].

Indeed, the synergistic possibilities offered by geographic proximity is considered a defining feature for implementing inter-firm approaches [37] such as Industrial Symbiosis (IS) and Eco-industrial Parks (EIP). Academic community has recognized IS as a process of connecting flows among industrial actors through by-product exchange, utility sharing and joint service provision [38]. In turn, EIP has been recognized as a referential model in which a community of co-located companies seeks 
environmental, economic and social benefits, through material, energy and information exchange (IS) [39]. From a technical or an operational perspective, EIP present some key elements such as infrastructure and utility sharing, common services and waste exchange, which contribute to the efficient use of resources.

Previous studies on IE practice and theory [38,40-49] have mainly focused on industrial clusters, revealing an opportunity to shift the attention to construction sites. IE potential contributions for managing environmental and resources issues in construction sites, where communities of companies pertaining to construction industry are co-located (contractors, subcontractors, client, etc.) have not yet been discussed. The present paper aims to investigate IE contributions to waste management in industrial construction. The waste management strategies adopted in two industrial construction projects in Brazil are analyzed in order to investigate if industrial construction sites can benefit from the synergies offered by geographical proximity between contractors, similarly to what is observed in EIP.

\section{Materials and Methods}

In the first decade of the 2000s, the construction industry in Brazil presented an expressive growth due to governmental investment programs and regulatory issues that brought more security to private investors [50]. Within this context, several industrial, commercial and institutional construction projects were implemented throughout the country, revealing opportunity to conduct a case study focused on construction waste management. Due to industrial construction technical and managerial complexity, to the involvement of several contractors and to the significant waste generation in such projects, the present paper focuses on industrial construction.

The case study method is, therefore, adopted in the present paper, once it permits the investigation of a phenomenon within a real context, allowing exploration towards how improvements can be made in the object of analysis [51]. In order to ensure the rigor of the case study method, the three stage research process proposed by Yin [51] is employed, as illustrated in Figure 1.

\begin{tabular}{|c|c|c|}
\hline Research method & & Research activities \\
\hline \multirow{2}{*}{$\begin{array}{c}\text { Case study } \\
\text { design }\end{array}$} & 1) & Formulate research question \\
\hline & 2) & Define unit of analysis \\
\hline \multirow{2}{*}{ Data collection } & 1) & Collect data on types and quantities of waste \\
\hline & 2) & Collect information on waste management practices \\
\hline \multirow{3}{*}{ Data analysis } & 1) & Characterize the independent waste management strategy \\
\hline & 2) & Characterize the joint waste management strategy \\
\hline & 4) & $\begin{array}{l}\text { Discuss if industrial construction sites can benefit from } \\
\text { synergies offered by proximity between contractors similarly } \\
\text { to what is observed in EIP. }\end{array}$ \\
\hline
\end{tabular}

Figure 1. Research method.

In the first stage, the research question is formulated aiming at investigating how IE can contribute to waste management in industrial construction. An initial survey on industrial construction in Brazil was conducted and some projects in oil and gas sector were identified. The final client of these projects (company that operate the plants after construction) was contacted and preliminary information about the waste management strategies adopted in these projects was evaluated. Based on this preliminary information, two industrial construction projects were selected for the present analysis, once both adopted some practices aligned with IE concepts, being representative for the purpose of the present paper.

The waste management strategies adopted in the industrial construction projects selected (Project A and Project B) are defined as the object of analysis. Both projects comprise the construction of process units in oil and gas $(\mathrm{O} \& \mathrm{G})$ industrial plants in Brazil. Equipment has been sourced from manufacturers in Brazil and abroad. In each project, contractors, subcontractors and the client 
(the O \& G company) are co-located at the same project site. In Project A, an independent waste management strategy is adopted, i.e., each contractor manages the waste generated in its activities. In Project B, a joint waste management strategy, based on inter-firm practices, is implemented. In this strategy, the waste generated in the activities of all contractors involved in the project are managed jointly. Both projects required capital investment of millions of dollars, had a long construction period and involved several construction actors, as presented in Table 1. The projects are located in the same Brazilian region (South-East), near to urban centers (less than $20 \mathrm{~km}$ ), in industrialized areas. The South-East region is the most industrialized region in the country. Construction, food, oil and gas, petrochemical, automobile and chemical are the main industrial sectors in the region [52]. According to the Brazilian National Plan of Solid Wastes [53], 51,582 t of construction waste is collected daily in the South-East, the higher quantity verified between all Brazilian regions. Thus, proper waste management practices can contribute to reduce construction environmental impact in the region. Brazilian legislation inputs the responsibility by the management of the waste generated in construction activities to the contractors that generate them [53].

Table 1. Project's main characteristics.

\begin{tabular}{lll}
\hline & \multicolumn{1}{c}{ Project A } & \multicolumn{1}{c}{ Project B } \\
\hline Scope & $\begin{array}{l}\text { Design and construction of four } \\
\text { process units in an onshore } \\
\text { O\& } \mathrm{G} \text { plant. }\end{array}$ & $\begin{array}{l}\text { Design and construction of six } \\
\text { process units in an onshore } \\
\text { O \& G plant. }\end{array}$ \\
\hline General characteristics & $\begin{array}{l}\text { Unit with lower daily processing } \\
\text { capacity in the project: } 3000 \mathrm{~m}^{3} / \mathrm{d}\end{array}$ & $\begin{array}{l}\text { Unit with lower daily processing } \\
\text { capacity in the project: } 4000 \mathrm{~m}^{3} / \mathrm{d}\end{array}$ \\
\hline Time length & Seven years & Six years \\
\hline Number of contractors involved & Five & Eight \\
\hline Waste management strategy & $\begin{array}{l}\text { Independent waste } \\
\text { management strategy. }\end{array}$ & Joint waste management strategy. \\
\hline Waste generation & 45,460 $\mathrm{t}$ & $53,820 \mathrm{t}$ \\
\hline
\end{tabular}

In the second stage, data about the waste management strategies adopted in each project is collected. Multiple sources of information are employed, including direct observation (visits to the projects' sites), examination of available documents (environmental management system documents, contracts and licenses) and evaluation of archival records (quantitative waste management data regarding waste generation, recycling, diversion from landfilling and waste recovery through Industrial Symbiosis).

In the third stage, the waste management strategies adopted in Projects A and B are analyzed. The set of indicators presented in Table 2 is employed to analyze quantitative data. These indicators were selected based on previous studies about waste management systems indicators [54-58] and on studies focused on waste recovery through Industrial Symbiosis [23,31]. We consider that Industrial Symbiosis comprises inter-firm waste exchanges focused on reintegration of waste and by-products into production activities, including construction activities. Contractor-contractor waste exchange relations are considered as Industrial Symbiosis, while inter-firm relations between contractors and waste receivers (waste recycling, treatment or disposal companies) are not considered Industrial Symbiosis relations.

The adoption of synergistic practices on the industrial construction projects under analysis is investigated. Table 3 presents the synergistic practices, commonly observed in EIP, selected for investigation. Synergies related to energy exchange, logistic and water and wastewater treatment are not investigated. 
Table 2. Description of adopted indicators.

\begin{tabular}{ll}
\hline \multicolumn{1}{c}{ Indicators } & \multicolumn{1}{c}{ Definition } \\
\hline Recycling rate & $\begin{array}{l}\text { Rate of solid waste recycled per total amount of solid } \\
\text { waste generated (expressed as percent). }\end{array}$ \\
\hline Diversion rate & $\begin{array}{l}\text { Rate of solid waste diverted from landfilling per total } \\
\text { amount of solid waste generated (expressed as } \\
\text { percent). Diversion rate comprises reuse, recycling } \\
\text { and other waste recovery and treatment alternatives, } \\
\text { corresponding to the waste diverted from landfills. }\end{array}$ \\
\hline Rate of waste recovered through Industrial Symbiosis & $\begin{array}{l}\text { Rate of solid waste recovered through waste } \\
\text { exchange between firms per total amount of solid } \\
\text { waste generated (expressed as percent). }\end{array}$ \\
\hline
\end{tabular}

Source: adapted from Greene and Tonjes [58], Bain et al. [23] and Patrício [31].

Table 3. Some Eco-Industrial Park synergistic practices.

\begin{tabular}{ll}
\hline \multicolumn{1}{c}{ Elements } & \multicolumn{1}{c}{ Description } \\
\hline Engagement of actor involved & $\begin{array}{l}\text { Engagement of key actors is essential to successful } \\
\text { implementation of EIP. }\end{array}$ \\
\hline Common services & $\begin{array}{l}\text { Sharing ancillary services, such as waste } \\
\text { management, transportation and landscaping. }\end{array}$ \\
\hline Shared infrastructure & $\begin{array}{l}\text { Pooled use and management of common } \\
\text { infrastructure such as waste storage area, solvent } \\
\text { recycling center, warehouse, restaurants, meeting } \\
\text { rooms, ambulatory, among others. }\end{array}$ \\
\hline By-products and solid waste synergies & $\begin{array}{l}\text { Waste, by-products and scraps exchange, supporting } \\
\text { the exchange of materials and handling some } \\
\text { by-products marketed off-site. }\end{array}$ \\
\hline Management aspects & $\begin{array}{l}\text { Administrative simplification due to the use of } \\
\text { common procedures, a single environmental } \\
\text { management system and common licenses. }\end{array}$ \\
\hline & Source: based on Taddeo [35], Lowe [59], Veiga [60].
\end{tabular}

Finally, the synergistic practices adopted and the results achieved by the projects are compared and, a SWOT analysis (Strengths, Weaknesses, Opportunities and Threats) of the joint waste management strategy adopted in Project B is carried out, since in this strategy more synergistic practices, similar to those commonly adopted in EIP, were observed. A series of workshops has been conducted to accomplish this. Five environmental specialists involved with the projects, as well as, one of the authors of this paper, attended the workshops. Based on the SWOT analysis, the potential and limits of application of the synergistic practices listed in Table 3 in industrial construction is discussed.

\section{Results}

\subsection{Project A: Independent Waste Management Strategy}

In the independent waste management strategy adopted in Project A, each contractor is responsible for managing the waste generated by its activities. The waste management process (waste segregation, collection, storage, transportation and final treatment) is conducted independently by each contractor. At the end of the month, the five contractors prepare waste inventories and present them to the final client in order to demonstrate legal compliance. Infrastructure sharing and common procedures are not observed. Figure 2 illustrates the waste management strategy of this project. Waste's flows from the generation points to five waste storage areas in the construction site (one for each contractor) and, then, to waste receivers are represented, as well as, information's flows between contractors and the final client. 
Data analysis revealed that $0.3 \%$ of the waste generated during the project corresponds to hazardous waste, while $99.7 \%$ are non-hazardous. The main waste streams are concrete and wood, aligned with previous findings in the literature [61]. The remaining parcel includes metal scraps, plastic, paper, hazardous waste, among others. The average waste flow from the construction site to final destinations observed is $540 \mathrm{t} /$ month. During the construction period, waste was sent to 33 different facilities (landfills, waste treatment units and companies in other industrial sectors), most of which located within a radius of $90 \mathrm{~km}$ from the construction site. More than $99 \%$ of the wastes were sent to facilities within this radius.

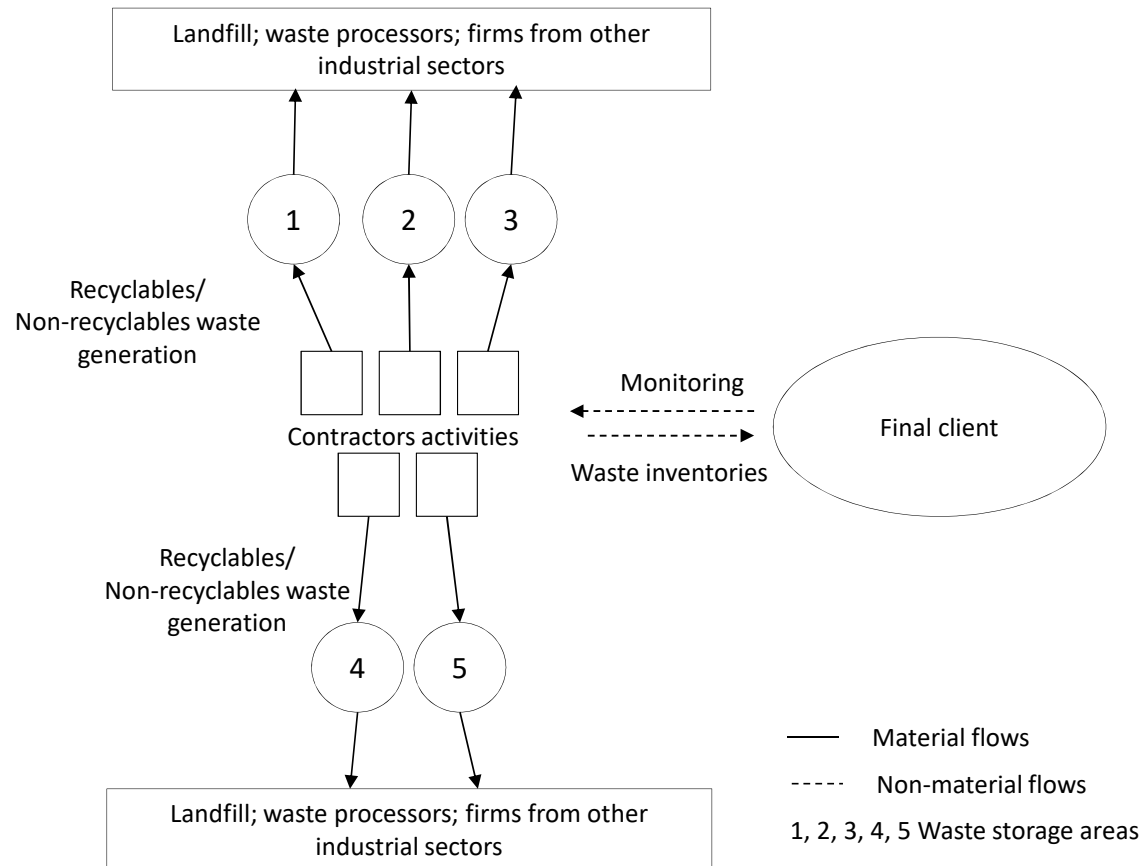

Figure 2. Independent waste management strategy.

During the project, $43 \%$ of the waste generated was diverted from landfilling, $11 \%$ was recycled and $30 \%$ was recovered through IS (waste exchange between companies). Regarding waste recovery through IS, $27 \%$ of hazardous wastes ( $38 \mathrm{t}$ ) were destined for co-processing by a cement manufacturer, $78 \%$ of abrasive disc cutters generated by the construction activities $(8 \mathrm{t})$ was destined, after use, for recovery by an abrasive grains manufacturer outside the construction site, $93 \%$ of mineral wool residues $(4 t)$ was destined for a ceramic manufacturer and $34 \%$ of concrete debris were sent to a contractor, avoiding landfilling of more than 13,000 $\mathrm{t}$ of waste. Table 4 presents the overall diversion, recycling and waste recovery through IS rates of the project, as well as, the individual rates of each contractor. One contractor (F1) has achieved a diversion rate higher than the others. F1 has sent concrete debris (broken concrete without protruding metal bars) to a contractor involved in a construction project located in the same municipality of Project A. The concrete debris were employed for activities related to grading process.

Table 4. Diversion rates, recycling rates, waste recovery rates through Industrial Symbiosis (IS).

\begin{tabular}{cccc}
\hline & Diversion Rate (\%) & Recycling Rate (\%) & Waste Recovery Rate through IS (\%) \\
\hline Project A & 43 & 11 & 30 \\
F1 & 78 & 10 & 65 \\
F2 & 34 & 22 & 12 \\
F3 & 15 & 15 & 0 \\
F4 & 3 & 3 & 0 \\
F5 & 1 & 0.6 & 0 \\
\hline
\end{tabular}


The indicators presented in Table 4 reveals that waste management performance is not uniform between the contractors involved in the project. Once each contractor is responsible for managing all waste generated in its activities, different performances may occur, as observed in this case. In order to avoid that some contractors present low waste management performances in projects such as this one, impacting the project's overall performance, one possible alternative is to implement new approaches to managing waste.

\subsection{Project B: Joint Waste Management Strategy}

In the joint waste management strategy adopted in Project B, all waste generated in the construction activities developed by the contractors is handled jointly. All parties involved in the project are responsible for some waste management steps. An organization specialized in waste management is contracted and held responsible for waste collection, storage and transport to recycling, treatment or disposal facilities. The specialized organization also provides waste bins all over the construction site and manages the shared waste storage area. In turn, the final client assign personnel to coordinate the waste management process. This team schedules waste collection services in work fronts, obtains the licenses and other legal documents for waste transport and destination, and sponsors meetings between contractors and the waste management organization in order to share information, plan waste management services and improve the process. Finally, waste segregation in the generation points and training programs for workers are placed under the responsibility of contractors. A single waste management plan is adopted by the actors involved, reinforcing the integration between them.

Empirical observation from the present case study revealed that, concerning the actors involved, the implementation of a joint waste management strategy is mainly driven by the final client's initiative. Final client participation is fundamental to encourage collaboration between contractors. Indeed, the final client acted as a coordinating organization. Patala et al. [62] state that coordinating organizations can provide a tremendous boost to network's collaboration activities.

A solvent recycling center, installed in the construction site, allowed solvent recovery, reducing virgin material use and purchase costs. The investment necessary to install the solvent recycling center was recovered in six months of operation, during which approximately $500 \mathrm{~L} / \mathrm{month}$ of solvent were recycled. Figure 3 illustrates the waste management strategy of this project. Waste's flows from the generation points to a common waste storage area in the construction site and, then, to waste receivers are represented, as well as, information's flows between contractors and the final client. Collaboration between the parties involved is also represented.

During the project, $0.6 \%$ of the generated waste corresponds to hazardous waste, while $99.4 \%$ is non-hazardous. The main waste streams observed in the project are also concrete and wood. An average of $750 \mathrm{t} /$ month of waste was collected by the waste management organization in the industrial construction site. During the construction period, waste was transported to 14 different destinations (landfills, waste processors and other companies), most of which located within a radius of $125 \mathrm{~km}$ from the construction site. More than $99 \%$ of the waste generated was sent to facilities within this radius. Data analysis indicates that $55 \%$ of the waste generated during the project was diverted from landfilling and $45 \%$ was recycled. Approximately, $2 \%$ of hazardous waste was destined for co-processing by a cement manufacturer $(7.5 \mathrm{t}$ ) and $99 \%$ of wood waste (4987 $\mathrm{t}$ ) was sent to a wood processing company. Despite the small amount of waste sent for co-processing, it corresponded to a significant parcel of hazardous waste diverted from landfilling. It was verified that $5 \%$ of hazardous waste was diverted from landfills.

Thus, waste exchange between contractors and companies outside the construction site (cement manufacturer and wood processing company) were observed. During the project, $9 \%$ of the waste generated was recovered through these waste exchange connections, contributing to elevate the diversion rate. The remaining $91 \%$ of the waste produced was managed through 12 connections between contractors and waste receivers. 


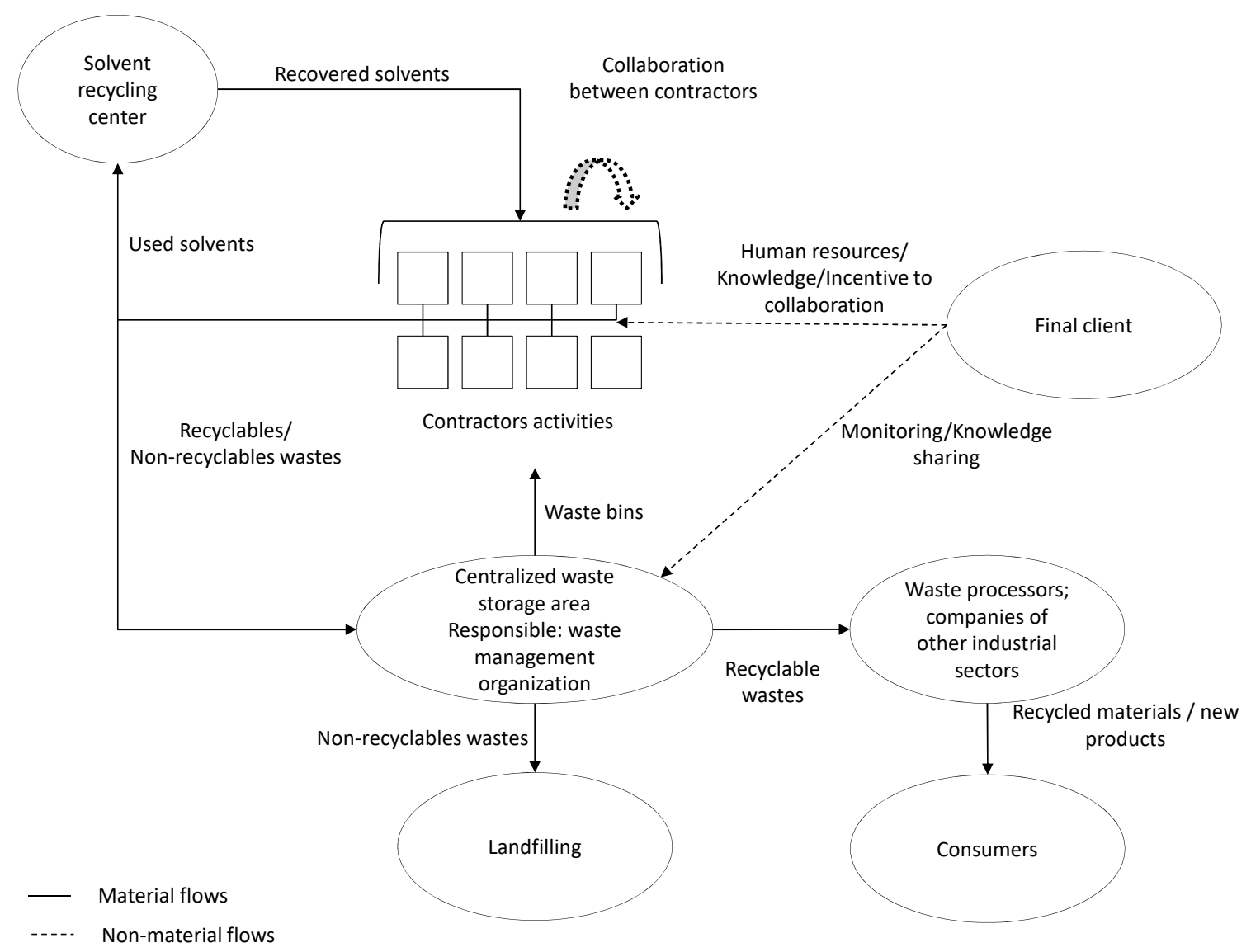

Figure 3. Joint waste management strategy.

The implementation of the joint waste management strategy was motivated not only by performance aspects, but also by regulatory issues and awareness with environmental risks related to inadequate waste disposal. In order to assure legal compliance during construction activities, the final client can adopt a monitoring or a collaboration approach with contractors. In the independent waste management strategy adopted in Project A, a monitoring approach is observed, while in the joint waste management strategy adopted in Project B, a collaboration strategy is implemented.

\subsection{Comparative Analysis}

Figure 4 presents recycling rates, waste recovery rates through IS and the rates of waste sent to other treatment alternatives for each project analyzed. Waste diverted from landfilling corresponds to the sum of the waste recycled, the waste recovered through IS and the waste sent to other treatment alternatives. As depicted in Figure 4, the diversion and recycling rates observed in Project B were both higher than those observed in Project A. The wide range of waste diversion and recycling rates observed between the contractors involved in Project B, presented in Section 3.2, affected the project overall performance. Waste recovery through IS contributed to elevate diversion rate in both projects, avoiding landfilling. 


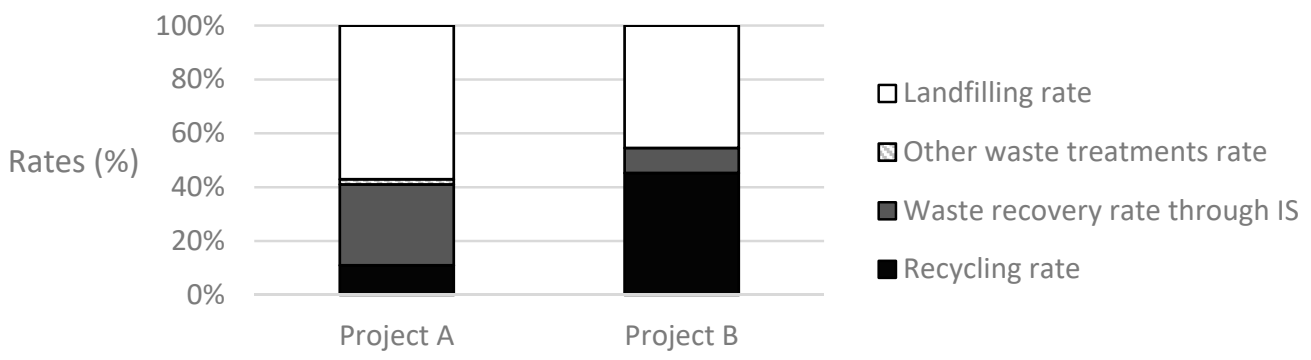

Figure 4. Waste destination in Projects A and B.

In Project A, waste exchanges between the contractors and companies outside the site were observed. Other synergistic practices investigated in the present research were not observed in this project, i.e., adoption of common services, infrastructure sharing and integrated management. In turn, in Project B, besides the waste exchanges observed between contractors and other companies, centralization of waste management services through a specialized waste management organization, sharing of waste storage area and administrative simplifications due to the collaboration between the actors involved were observed. In order to deepen understanding of the potential and limits of application of such synergistic practices in industrial construction sites, a SWOT analysis of the joint waste management strategy was carried out and its results are presented in next section.

\subsection{SWOT Analysis}

A series of workshops with the technical staff involved in Projects A and B was carried out. During the workshops, the strengths, weaknesses, opportunities and threats of the joint waste management strategy were identified, as presented in Table 5.

Table 5. Joint waste management strategy SWOT analysis.

\begin{tabular}{ll}
\hline - & $\begin{array}{l}\text { Engagement of a specialized waste management organization } \\
\text { Sharing of a single waste storage area }\end{array}$ \\
- & $\begin{array}{l}\text { Administrative simplification: a single waste management system for all } \\
\text { parties involved } \\
\text { Industrial construction firms dedicated exclusively to their core activity }\end{array}$ \\
Weaknesses & $\begin{array}{l}\text { Once this strategy depends on collaboration, conflicts between the parties involved } \\
\text { are more likely to occur }\end{array}$ \\
\hline - & $\begin{array}{l}\text { If coordinating team is indispensable to the waste management process } \\
\text { waste collection in the construction site can be delayed, affecting } \\
\text { construction activities }\end{array}$ \\
\hline Opportunities & $\begin{array}{l}\text { Public incentives to environmental initiatives such as Industrial Ecology, Cleaner } \\
\text { Production, etc. } \\
\text { License conditions requiring adoption of collaboration practices, integrated reports } \\
\text { and a single waste management plan }\end{array}$ \\
\hline Threats & $\begin{array}{l}\text { Availability of waste treatment/disposal facilities in the region } \\
\text { Preference for contract agreements in which each contractor is responsible for } \\
\text { managing its own waste }\end{array}$ \\
\hline
\end{tabular}

The SWOT analysis reveals that the strengths of the joint waste management strategy derive, mainly, from the advantages propitiated by the centralized management of waste provided by the engagement of a specialized waste management organization. Higher efficiency and increased service 
quality are considered typical benefits of joint service provision, as well as material and energy potential intensity reduction, once individual firms do not have to own ancillary infrastructure and equipment when using a common provider [63].

The engagement of a specialized waste management organization can assure uniformity in waste management practices in the construction site, contributing to enhance project's overall environmental performance. In addition, sharing a single waste storage area contributes to a better layout and to logistic aspects, once construction sites do not have much space for waste management equipment and storage of construction waste [64]. Administrative simplification is also a strength of the joint waste management strategy, once a common waste management plan guides the actions of all actors involved and the coordinating team obtains the documents necessary for waste transport and destination for all contractors involved with the project.

Once the joint waste management strategy requires cooperation between all parties, clear definitions of tasks, responsibilities and interfaces are essential to avoid conflicts. One of the weaknesses identified in the SWOT analysis is the potential occurrence of conflicts between the parties involved in the joint waste management strategy. Another weakness is related to dependency on a dedicated team for coordinating the inter-organizational activities. Without a coordinating team, problems related to service schedule and communication can occur. In Project B, a coordinating team formed by final client's staff was assigned to this process. The final client acted as a coordinating organization, encouraging collaboration between the firms involved and presenting great influence in the decision-making process.

The opportunities identified through the SWOT analysis comprise public incentives offered by local government to encourage the implementation of collaboration and IE practices. Licence conditions requiring the establishment of collaboration practices between the organizations involved in the project is also a driver to joint waste management strategy implementation. As long as all firms are involved in the same project, which is subjected to the same environment protection license, local environmental agencies can require joint information reports, aligned practices and a common waste management plan.

Availability of waste recycling and treatment alternatives may represent a threat to waste management, once it can impact recycling and diversion rates. In the present study, both projects occurred in the same Brazilian region (South-East). This region presents the best waste treatment structure of the country $[65,66]$.

Finally, contractors' preference for waste management strategies in which each contractor is responsible for managing its own waste represents another threat to joint waste management strategies. If the final client cannot find contractors willing to cooperate and engage in a joint waste management strategy, it becomes not viable.

The SWOT analysis revealed important features about the application of synergistic practices in industrial construction projects, providing inputs to the discussion presented in the next section.

\section{Discussion: Industrial Ecology Contributions}

As presented in Section 3, waste exchange, common services, shared infrastructure and administrative simplifications due to collaboration between contractors were observed in Project B, while in Project A only waste exchanges were observed. In this section, in order to investigate if industrial construction sites can benefit from synergies offered by the geographical proximity between contractors, similarly to what is observed in EIP, the results of the SWOT analysis have been employed to discuss the potential and limits of application of the synergistic practices mentioned in Section 2 (Table 3) in industrial construction. Aspects regarding the engagement of the actors in such practices are also discussed, as presented below.

Engagement of actors involved: previous findings reported in the literature highlight the importance of actors' commitment with the objectives and environmental policy in EIPs [35,59,60]. The role of a coordinating organization for EIPs and other eco-industrial networks is also highlighted in the 
literature [62]. Similarly, engaging all actors in waste management issues in a construction site is essential for its success $[19,67]$. In industrial construction projects, the actors involved with the waste management process are: contractors, subcontractors, the local environment protection agency, final client and an organization specialized in waste management services (when a joint waste management strategy is adopted). In the case study analyzed, the joint waste management strategy implementation was driven by the final client, motivated by performance aspects, legal requirements and awareness with environmental risks related to inadequate waste disposal, as discussed in Section 3.

From the experiences presented in this paper, it is possible to suggest that, in order to engage all actors in a waste management strategy based on inter-firm synergistic practices, the final client or a coordinating organization should: (i) search construction companies interested in the project and willing to engage in a joint waste management strategy; (ii) negotiate contracts; and (iii) elaborate a common waste management plan with responsibilities, activities, resources and schedule. Clear definition of tasks, responsibilities and interfaces between all parties involved through instruments, such as contracts and agreements, is fundamental to avoid conflicts. The role of contractual agreements for waste management has been already identified in the literature [8].

Common services: joint provision of services such as waste management, transport and landscaping is common practice in EIPs [60] and its advantages are reported in the literature [63]. In industrial construction projects, contractors can also benefit from the centralized waste management services provided by a specialized organization. Centralization of waste management may assure uniformity in the services provided for all contractors and subcontractors involved in the project, avoiding that some contractors present low waste management performances and, thus, contributing to enhance the project's overall performance. However, as revealed by the SWOT analysis, delays in the waste management services may impact industrial construction activities, once waste accumulation in the construction site can have negative effects on logistic and operational aspects. Thus, careful selection of the waste management organization that will be involved in the project is critical for the success of a joint waste management strategy. A coordinating team dedicated to schedule the services, encourage collaboration between all parties, assure good flow of communication and get the licences and other legal documents required to waste transport and destination can avoid delays.

Shared infrastructure: the pooled use and management of common infrastructure is a practice adopted in EIPs $[35,59,60,63]$ that presents potential to be implemented in construction sites, as suggested by the results presented in Section 3. In industrial construction projects, a single waste storage area can be shared by all companies involved in the project. Transport vehicles and waste bins can also be shared. Once there is not much space available for waste management infrastructure and waste storage in construction sites [64], contractors can benefit from sharing waste management infrastructure and equipment. In addition, solvent recycling centers and construction and demolition waste recycling centers can be installed in construction sites. Evaluation of technical and economic aspects must be executed in order to identify the best available option. Rent of mobile machines for specific periods of time or installation of stationary crushing machines, for example, are some of the options to be evaluated.

Material by-product and solid waste synergies: previous studies [34,37,42,63,68-70] suggest that industrial diversity is a key factor to create opportunities for by-product and waste exchange. Industrial Symbiosis can occur in single industry dominated clusters and multi-industry dominated ones [63]. Firms in single or related industries frequently share the same types of infrastructure and ancillary needs, so they can benefit from the joint provision of environmentally related services. Mixed industry clusters can benefit from utility sharing and the joint provision of non-industry-specific services, while their diversity can generate more options for resource complementarity and by-product exchange opportunities [71]. The case study analyzed in this paper, reveal that industrial construction sites behave as single-industry dominated clusters. Therefore, contractors can benefit from joint service provision, but waste exchange opportunities insight the site are not numerous. 
In turn, industrial construction activities produce waste streams that can be used by other industries outside the project's site. Thus, waste exchange opportunities between contractors within the site and industries outside the construction site boundaries should be searched. In Project A, abrasive disc cutters, after use, were destined for an abrasive grains manufacturer, mineral wool residues were sent for a ceramic manufacturer, hazardous waste was destined for co-processing by a cement manufacturer and concrete debris were destined for a contractor outside the project site. In Project B, wood waste was destined for a wood processing company and some hazardous waste was sent for co-processing by a cement manufacturer.

Results show that the waste recovery through IS observed in the industrial constructions projects in analysis are comparable to that reported in previous studies for industrial clusters. In Nanjangud Industrial Area, in India, for example, 18\% of waste generated was recovered through IS relations [23] and, in Lisbon Metropolitan Area, in Portugal, IS processed 23\% of the waste generated [31]. IS widens waste destination alternatives, contributing to avoid waste disposal in landfills. As demonstrated by the data collected in the present study, through IS, companies in different industrial sectors can receive waste produced in industrial construction activities and employ it on their production processes.

Table 6 presents a matrix with some typical waste streams generated in industrial construction projects and potential synergies with companies in other industrial sectors, i.e., companies that could receive the waste streams. This kind of matrix could be elaborated for industrial construction projects in planning stage, in order to identify waste synergies opportunities. Industrial diversity in the project's site surrounding region can contribute to the identification of more symbiotic opportunities.

Table 6. Waste synergy matrix.

\begin{tabular}{|c|c|c|c|c|c|c|c|c|}
\hline & \multicolumn{8}{|c|}{ Waste Streams } \\
\hline & 1 & 2 & 3 & 4 & 5 & 6 & 7 & 8 \\
\hline Abrasive grains manufacturer & $\mathrm{R}$ & & & & & & & \\
\hline Ceramic manufacturer & & $\mathrm{R}$ & & & & & & \\
\hline Wood-processing company & & & & & & & $\mathrm{R}$ & \\
\hline Cement manufacturer & & & & $\mathrm{R}$ & $\mathrm{R}$ & & & \\
\hline Steel manufacturing & & & $\mathrm{R}$ & & & $\mathrm{R}$ & & \\
\hline Other construction projects & & & & & & & & $\mathrm{R}$ \\
\hline Contractors in industrial construction projects & G & G & G & G & G & G & G & $\mathrm{R}$ \\
\hline
\end{tabular}

Management aspects: administrative simplification can be pointed out as a benefit of waste management strategies based on collaboration principles. A single waste management plan can be adopted by the actors involved. Similarly, a single waste management report can be elaborated and presented to the environment protection agency, when required. In addition, the coordinating team can obtain all the documents necessary for waste management. Finally, when a joint waste management approach is adopted, usually, waste are destined to a smaller number of recycling, treatment and disposal units, reducing the number of contractual agreements related to waste management in the project.

Aligned with previous studies [72-74], the case studied revealed that, before environmental collaboration implementation starts, the actors initially involved usually have already implemented their own environmental management systems. In addition, the literature indicates that implementation of joint environmental practices requires high level of commitment and integration between the actors involved [72,75,76], suggesting that this typology of practices is, probably, implemented after practices with lower complexity are already adopted.

This section presented a nuanced view about the adoption of synergistic practices offered by geographic proximity between the actors involved in industrial construction projects, highlighting 
some aspects that should be considered in order to successfully implementing such practices. Some benefits related to the implementation of these practices, as waste diversion from landfilling, reduction of the space occupied by waste management infrastructure in the construction site (better layout), uniformity in the waste management services provided for all contractors and administrative simplification, are pointed out.

\section{Conclusions}

The present paper investigated IE contributions to waste management in industrial construction projects, based on the analysis of the waste management strategies adopted in two industrial construction projects in Brazil. The main waste streams generated in the projects are identified and recycling and landfilling diversion rates are presented. The waste exchanges between contractors and other companies are also discussed.

Results show that, in both projects, more than $99 \%$ of the waste generated was non-hazardous and more than $40 \%$ of the total waste produced was diverted from landfills. Furthermore, $9 \%$ (Project B) and 30\% (Project A) of the waste generated in the projects was recovered through Industrial Symbiosis. Although Industrial Symbiosis opportunities between contractors on the project's site are not numerous, opportunities can be searched for with companies outside the site, contributing to resource efficiency within the broader framework of Circular Economy and to waste recovery in construction activities. Industrial Symbiosis brings new opportunities for recovering the industrial construction waste, besides waste treatment, reuse and recycling alternatives.

Despite Industrial Symbiosis having been observed in both projects, other synergistic practices comprised within the scope of Industrial Ecology were adopted only in the joint waste management strategy (Project B). Thus, a SWOT analysis on this waste management strategy was carried out, providing an in-depth analysis of these practices in the context of industrial construction.

In summary, the results of our study highlight that waste management in industrial construction projects can benefit from the following synergies commonly observed in IE place-based approaches: (i) centralized waste management service; (ii) shared waste management infrastructure within the site; (iii) administrative simplification for the companies involved; (iv) waste recovery through Industrial Symbiosis. However, the adoption of such synergistic practices depends on the engagement of the actors involved, on a coordinating team, on clear definition of tasks and responsibilities, as well as, on careful selection of a specialized waste management organization.

We propose that, in future projects, search for waste exchange opportunities through Industrial Symbiosis is carried out in the planning stage, based on the analysis of project's waste streams and of the industrial mix in the region surrounding the project's site. Centralization of waste management and infrastructure sharing must also be evaluated in planning stage.

The main contribution of this paper consists of shedding some light on the synergistic opportunities offered by geographic proximity between the actors involved in industrial construction projects, highlighting the potential application of Industrial Symbiosis and of other synergistic inter-firm practices. Additionally, although our study comprises industrial construction projects in $\mathrm{O} \& \mathrm{G}$ industry, the applicability of our results to projects in other sectors (e.g., electrical generation projects, mining projects, power plants projects, etc.) is promising, once industrial construction projects have common features in many sectors.

Finally, this paper contributes to research in waste management in industrial construction projects. Despite its importance for socio-economic development in all countries, there is a gap in the literature about waste management in these kind of projects.

Acknowledgments: We wish to thank the involved organizations for the data used in this study.

Author Contributions: All authors designed the study and discussed the first version of the research document. Freitas attended the workshops carried out during the study. All authors approved the final manuscript.

Conflicts of Interest: The authors declare no conflict of interest. 


\section{References}

1. Fuertes, A.; Casals, M.; Gangollels, M.; Forcada, N.; Macarulla, M.; Roca, X. An environmental impact causal model for improving the environmental performance of construction process. J. Clean. Prod. 2013, 52, 425-437. [CrossRef]

2. Li, Y.; Zhang, X. Web-based construction waste estimation system for building construction projects. Autom. Constr. 2013, 35, 142-156. [CrossRef]

3. Solís-Guzmán, J.; Marrero, M.; Montes-Delgado, M.V.; Ramírez-de-Arellano, A. A Spanish model for quantification and management of construction waste. Waste Manag. 2009, 29, 2542-2548. [CrossRef] [PubMed]

4. Llatas, C. A model for quantifying construction waste in projects according to the European list. Waste Manag. 2011, 31, 1261-1276. [CrossRef] [PubMed]

5. Calvo, N.; Varela-Candamio, L.; Novo-Corti, I. A dynamic model for construction and demolition (C\&D) waste management in Spain: Driving policies based on economic incentives and tax penalties. Sustainability 2014, 6, 416-435.

6. Tam, V.W.Y. On the effectiveness in implementing a waste-management plan method in construction. Waste Manag. 2008, 28, 1072-1080. [CrossRef] [PubMed]

7. Hao, J.L.; Hills, M.J.; Tam, V.W.Y. The effectiveness of Hong Kong's construction waste disposal charging scheme. Waste Manag. Res. 2008, 26, 553-558. [CrossRef] [PubMed]

8. Ajayi, S.O.; Oyedelle, L.O. Policy imperatives for diverting construction waste from landfill: Experts' recommendations for UK policy expansion. J. Clean. Prod. 2017, 147, 57-65. [CrossRef]

9. Sobotka, A.; Sagan, J. Cost-saving environmental activities on construction site-Cost efficiency of waste management: Case study. Procedia Eng. 2016, 161, 388-393. [CrossRef]

10. Linghard, H.; Graham, P.; Smithers, G. Employee perceptions of the solid waste management system operating in a large Australian contracting organization: Implications for company policy implementation. Constr. Manag. Econ. 2000, 18, 383-393. [CrossRef]

11. Yuan, H. Barriers and countermeasures for managing construction and demolition waste: A case of Shenzhen in China. J. Clean. Prod. 2017, 157, 84-93. [CrossRef]

12. Gangollels, M.; Casals, M.; Marcarulla, M. Analysis of the implementation of effective waste management practices in construction projects and sites. Resour. Conserv. Recycl. 2014, 93, 99-111. [CrossRef]

13. Ajayi, S.O.; Oyedele, L.O.; Bilal, M.; Akinade, O.; Alaka, H.A.; Owolabi, H.A. Critical management practices influencing on-site waste minimization in construction projects. Waste Manag. 2017, 59, 330-339. [CrossRef] [PubMed]

14. Begun, R.A.; Siwar, C.; Pereira, J.J.; Jaafar, A.H. Implementation of waste management and minimization in construction industry of Malaysia. Resour. Conserv. Recycl. 2007, 53, 321-328. [CrossRef]

15. Jiménez-Rivero, A.; Guzmán-Báez, A.; Garcia-Navarro, J. Enhanced on-site waste management of plasteboard in construction works: A case study in Spain. Sustainability 2017, 9, 450-461. [CrossRef]

16. Penteado, C.S.G.; Rosado, L.P. Comparison of scenarios for the integrated management of construction and demolition waste by life cycle assessment: A case study in Brazil. Waste Manag. Res. 2016, 34, 1026-1035. [CrossRef] [PubMed]

17. Oyedele, L.O.; Regan, M.; Meding, J.V.; Ahmed, A.; Ebohon, O.J.; Elnokaly, A. Reducing waste to landfill in the UK: Identifying impediments and critical solutions. World Rev. Sci. Technol. Sustain. Dev. 2013, 10, 131-142. [CrossRef]

18. Tam, V.W.Y.; Lu, W. Construction waste management profiles, practices and performance: A cross-jurisdictional analysis in four countries. Sustainability 2016, 8, 190-205. [CrossRef]

19. Udawatta, N.; Zuo, J.; Zillante, G. Improving waste management in construction projects: An Australian study. Resour. Conserv. Recycl. 2015, 101, 73-83. [CrossRef]

20. Veiga, L.B.E.; Magrini, A. Eco-industrial park development in Rio de Janeiro, Brazil: A tool for sustainable development. J. Clean. Prod. 2009, 17, 653-661. [CrossRef]

21. Ardente, F.; Cellura, M.; Lo Brano, V.; Mistretta, M. Life cycle assessment-driven selection of industrial ecology strategies. Integr. Environ. Assess. Manag. 2009, 6, 52-60.

22. Zhang, L.; Yuan, Z.; Bi, J.; Zhang, B.; Liu, B. Eco-industrial parks: National pilot practices in China. J. Clean. Prod. 2010, 18, 504-509. [CrossRef] 
23. Bain, A.; Shenoy, M.; Ashton, W.; Chertow, M. Industrial symbiosis and waste recovery in an Indian industrial area. Resour. Conserv. Recycl. 2010, 54, 1278-1287. [CrossRef]

24. Bai, L.; Qiao, Q.; Yang, Y.; Guo, J.; Xie, M. Insights on the development progress of National Demonstration Eco-industrial parks in China. J. Clean. Prod. 2014, 70, 4-14. [CrossRef]

25. Tian, J.; Liu, W.; Lai, B.; Li, X.; Chen, L. Study of the performance of eco-industrial park development in China. J. Clean. Prod. 2014, 64, 486-494. [CrossRef]

26. Van Berkel, R.; Fujita, T.; Hashimoto, S.; Geng, Y. Industrial and urban symbiosis in Japan: Analysis of Eco-Town program 1997-2006. J. Environ. Manag. 2009, 90, 1544-1556. [CrossRef] [PubMed]

27. Silva, A.; Rosano, M.; Stocker, L.; Gorissen, L. From waste to sustainable materials management: Three case studies of the transition journey. Waste Manag. 2017, 61, 547-557. [CrossRef] [PubMed]

28. Ghisellini, P.; Cialani, C.; Ulgati, S. A review on circular economy: The expected transition to a balanced interplay of environmental and economic systems. J. Clean. Prod. 2016, 114, 11-32. [CrossRef]

29. Velis, C.A. Circular economy and global secondary material supply chains. Waste Manag. Res. 2015, 33, 389-391. [PubMed]

30. Wilts, H.; von Gries, N.; Bahn-Walkowiak, B. From waste management to resource efficiency-The need for policy mix. Sustainability 2016, 8, 622-637. [CrossRef]

31. Patrício, J.; Costa, I.; Niza, S. Urban material cycle closing-Assessment of industrial waste management in Lisbon region. J. Clean. Prod. 2015, 106, 389-399. [CrossRef]

32. Hu, D.; Mohamed, Y. A dynamic programming solution to automate fabrication sequencing of industrial construction components. Autom. Constr. 2014, 40, 9-20. [CrossRef]

33. Tian, J.; Shi, H.; Chen, Y.; Chen, L. Assessment of industrial metabolisms of sulfur in a Chinese fine chemical industrial park. J. Clean. Prod. 2012, 32, 262-272. [CrossRef]

34. Simboli, A.; Taddeo, R.; Morgante, A. The potential of industrial ecology in agri-food clusters (AFCs): A case study based on valorisation of auxililary materials. Ecol. Econ. 2015, 111, 65-75. [CrossRef]

35. Taddeo, R. Local industrial systems towards the eco-industrial parks: The model of the ecologically equipped industrial areas. J. Clean. Prod. 2016, 131, 189-197. [CrossRef]

36. Tseng, M.; Bui, T. Identifying eco-innovation in industrial symbiosis under linguistic preferences: A novel hierarchical approach. J. Clean. Prod. 2017, 140, 1376-1389. [CrossRef]

37. Chertow, M.; Ehrenfeld, J. Organizing self-organizing systems. J. Ind. Ecol. 2012, 16, 13-27. [CrossRef]

38. Boons, F.; Chertow, M.R.; Park, J.; Spekkink, W.; Shi, H. Industrial symbiosis dynamics and the problem of equivalence: Proposal for a comparative framework. J. Ind. Ecol. 2016. [CrossRef]

39. Côte, R.P.; Cohen-Rosenthal, E. Designing eco-industrial parks: A synthesis of some experiences. J. Clean. Prod. 1998, 6, 181-188. [CrossRef]

40. Korhonen, J. Regional industrial ecology: Examples from regional economic systems of forest industry and energy supply in Finland. J. Environ. Manag. 2001, 63, 367-375. [CrossRef] [PubMed]

41. Baas, L.W.; Boons, F.A. An industrial ecology project in practice: Exploring the boundaries of decision-making levels in regional industrial systems. J. Clean. Prod. 2004, 12, 1073-1085. [CrossRef]

42. Zhu, Q.; Cote, R.P. Integrating green supply chain management into an embryonic eco-industrial development: A case study of the Guitang Group. J. Clean. Prod. 2004, 12, 1025-1035. [CrossRef]

43. Chertow, M.R. Uncovering industrial symbiosis. J. Ind. Ecol. 2007, 11, 11-30. [CrossRef]

44. Fang, Y.; Raymond, P.C.; Qin, R. Industrial sustainability in China: Practice and prospects for eco-industrial development. J. Environ. Manag. 2007, 83, 315-328. [CrossRef] [PubMed]

45. Ashton, W. Understanding the organization of industrial ecosystems. J. Ind. Ecol. 2008, 12, 34-51. [CrossRef]

46. Ashton, W.S. The structure, function and evolution of a regional industrial ecosystem. J. Ind. Ecol. 2009, 13, 228-246. [CrossRef]

47. Park, H.; Rene, E.R.; Choi, S.; Chiu, A.S.F. Strategies for sustainable development of industrial park in Ulsan, South Korea-From spontaneous evolution to systematic expansion of industrial symbiosis. J. Environ. Manag. 2008, 87, 1-13. [CrossRef] [PubMed]

48. Boons, F.; Spekkink, W.; Mouzakitis, Y. The dynamics of industrial symbiosis: A proposal for a conceptual framework based upon a comprehensive literature review. J. Clean. Prod. 2011, 19, 905-911. [CrossRef]

49. Despeisse, M.; Ball, P.D.; Evans, S.; Levers, A. Industrial ecology at factory level-A conceptual model. J. Clean. Prod. 2012, 31, 30-39. [CrossRef] 
50. Centro de Gestão e Estudos Estratégicos (CGEE). Estudo do Panorama Setorial de Construção Civil; Centro de Gestão e Estudos Estratégicos: Brasília, Brazil, 2009.

51. Yin, R.K. Estudo de Caso: Planejamento e Métodos, 2nd ed.; Bookman: São Paulo, Brazil, 2001.

52. Confederação Nacional da Indústria (CNI). Portal da Indústria. Available online: http://perfilestados. portaldaindustria.com.br (accessed on 15 May 2017).

53. Ministério do Meio Ambiente (MMA). Plano Nacional de Resíduos Sólidos. Available online: http://mma. gov.br/estruturas/253/publicacao/253_publicacao 02022012041757.pdf (acessed on 18 June 2017).

54. Armijo, C.; Puma, A.; Ojeda, S. A set of indicators for waste management programs. In Proceedings of the 2nd International Conference on Environmental Engineering and Applications, Shangai, China, 19-21 August 2011; LACSIT Press: Singapore, 2011.

55. Desmond, M. Municipal solid waste management in Ireland: Assessing for sustainability. Ir. Geogr. 2006, 39, 22-33. [CrossRef]

56. Santiago, L.S.; Dias, S.M.F. Matriz de indicadores de sustentabilidade para gestão de resíduos sólidos urbanos. Engenharia Sanitária Ambiental 2012, 17, 203-212. [CrossRef]

57. Zaman, A.U. Identification of key assessment indicators of the zero waste management systems. Ecol. Indic. 2014, 36, 682-693. [CrossRef]

58. Greene, K.L.; Tonjes, D.J. Quantitative assessments of municipal waste management systems: Using different indicators to compare and rank programs. Waste Manag. 2014, 34, 825-836. [CrossRef] [PubMed]

59. Lowe, E. Eco-Industrial Park Handbook for Asian Developing Countries; Indigo Development: Oakland, CA, USA, 2001; Available online: http:/ /indigodev.com (accessed on 6 May 2017).

60. Veiga, L.B. Diretrizes Para a Implantação de um Parque Industrial Ecológico: Uma Proposta Para o PIE de Paracambi, RJ. Ph.D. Thesis, Federal University of Rio de Janeiro, Rio de Janeiro, Brazil, 2007.

61. Malia, M.; Brito, J.; Pinheiro, M.D.; Bravo, M. Construction and demolition waste indicators. Waste Manag. Res. 2013, 31, 241-255. [CrossRef] [PubMed]

62. Patala, S.; Hämäläinen, S.; Jalkala, A.; Pesonen, H. Towards a broader perspective on the forms of eco-industrial networks. J. Clean. Prod. 2014, 82, 166-178. [CrossRef]

63. Chertow, M.R.; Ashton, W.; Espinosa, J.C. Industrial symbiosis in Puerto Rico: Environmentally related agglomeration economies. Reg. Stud. Assoc. 2008, 42, 1299-1312. [CrossRef]

64. Wang, J.; Yuan, H.; Kang, X.; Lu, W. Critical success factors for on-site sorting of construction waste: A China study. Resour. Conserv. Recycl. 2010, 54, 931-936. [CrossRef]

65. Associação Brasileira de Empresas de Tratamento de Resíduos (ABETRE). Perfil do Setor de Tratamento de Resíduos. 2013. Available online: http:/ /www.abetre.org.br/biblioteca/publicacoes/publicacoes-abetre/ copy2_of_ABETREPerfildoSetordeTratamentodeResduos042013.pdf (accessed on 25 May 2017).

66. Associação Brasileira para Reciclagem de Resíduos da Construção Civil e Demolição (ABRECON). Pesquisa Setorial Abrecon. 2013. Available online: https://issuu.com/sanchocom/docs/pesquisa_setorial_abrecon_ 2013 (accessed on 25 May 2017).

67. Manowong, E. Investigating factors influencing construction waste management efforts in developing countries: An experience from Thailand. Waste Manag. Res. 2017, 30, 56-71. [CrossRef] [PubMed]

68. Pajunen, N.; Watkins, G.; Wierink, M.; Heiskanen, K. Drivers and barriers of effective industrial material use. Miner. Eng. 2012, 29, 39-46. [CrossRef]

69. Raut, R.D.; Narkhede, B.; Gardas, B.B. To identify the critical success factors of sustainable supply chain management practices in the context of oil and gas industries: ISM approach. Renew. Sustain. Energy Rev. 2017, 68, 33-47. [CrossRef]

70. COPPE-UFRJ-IBAM. Revisão do Zoneamento Industrial da Região Metropolitana do Rio de Janeiro: Diagnóstico Consolidado e Banco de Dados Georeferenciado; Consórcio COPPE-UFRJ-IBAM: Rio de Janeiro, Brazil, 2000.

71. Jensen, P.D. The role of geospatial industrial diversity in the facilitation of regional industrial symbiosis. Resour. Conserv. Recycl. 2016, 107, 92-103. [CrossRef]

72. Gavronski, I.; Klassen, R.D.; Vachon, S.; Nascimento, L.F.M.D. A resource-Based view of green supply management. Transp. Res. Part E 2011, 47, 872-885. [CrossRef]

73. Jabbour, A.B.L.S. Understanding the genesis of green supply chain management: Lessons from leading Brazilian companies. J. Clean. Prod. 2015, 87, 385-390. [CrossRef] 
74. Koplin, J.; Seuring, S.; Mesterharm, M. Incorporating sustainability into supply management in the automotive industry-The case of Volkswagen AG. J. Clean. Prod. 2007, 15, 1053-1062. [CrossRef]

75. Pero, M.; Moretto, A.; Bottani, E.; Bigliardi, B. Environmental collaboration for sustainability in the construction industry: An exploratory study in Italy. Sustainability 2017, 9, 125. [CrossRef]

76. Reefke, H.; Sundaram, D. Key themes and research opportunities in sustainable supply chain management-Identification and evaluation. Omega 2017, 66, 195-211. [CrossRef] 